IZA DP No. 8204

The Effects of the Great Recession on Teenagers'

Risky Health Behaviors and Time Use

Sabrina Wulff Pabilonia

May 2014 


\title{
The Effects of the Great Recession on Teenagers' Risky Health Behaviors and Time Use
}

\author{
Sabrina Wulff Pabilonia \\ U.S. Bureau of Labor Statistics \\ and IZA \\ Discussion Paper No. 8204 \\ May 2014 \\ IZA \\ P.O. Box 7240 \\ 53072 Bonn \\ Germany \\ Phone: +49-228-3894-0 \\ Fax: +49-228-3894-180 \\ E-mail: iza@iza.org
}

\begin{abstract}
Any opinions expressed here are those of the author(s) and not those of IZA. Research published in this series may include views on policy, but the institute itself takes no institutional policy positions. The IZA research network is committed to the IZA Guiding Principles of Research Integrity.

The Institute for the Study of Labor (IZA) in Bonn is a local and virtual international research center and a place of communication between science, politics and business. IZA is an independent nonprofit organization supported by Deutsche Post Foundation. The center is associated with the University of Bonn and offers a stimulating research environment through its international network, workshops and conferences, data service, project support, research visits and doctoral program. IZA engages in (i) original and internationally competitive research in all fields of labor economics, (ii) development of policy concepts, and (iii) dissemination of research results and concepts to the interested public.
\end{abstract}

IZA Discussion Papers often represent preliminary work and are circulated to encourage discussion. Citation of such a paper should account for its provisional character. A revised version may be available directly from the author. 


\section{ABSTRACT \\ The Effects of the Great Recession on Teenagers'
Risky Health Behaviors and Time Use}

This paper uses individual-level data from both the 2003-2011 American Time Use Survey and Youth Risk Behavior Survey and state-level unemployment rates to examine the effects of the Great Recession on teenagers' activities. I present results by gender and gender by race/ethnicity. Over the period, I find changes in sexual activity for males associated with changes in time spent with parents; but results vary significantly by race. In addition, Hispanic males gained weight during the recession, due perhaps to a decrease in time spent playing sports. Hispanic females, on the other hand, made greater educational investments while spending less time working. All females significantly decreased TV viewing during the Great Recession. However, there were signs that female teenagers were stressed as they slept less and were more likely to smoke regularly.

JEL Classification: J22, J11

Keywords: $\quad$ teenagers, risky behaviors, time use, Great Recession, economy

Corresponding author:

Sabrina Wulff Pabilonia

U.S. Bureau of Labor Statistics

2 Massachusetts Ave. NE, Rm. 2180

Washington, DC 20212

USA

E-mail: Pabilonia.Sabrina@bls.gov

\footnotetext{
* All views expressed are those of the author and do not necessarily reflect the views or policies of the U.S. Bureau of Labor Statistics. I would like to thank Melinda Sandler Morrill, Younghwan Song, Charlene Kalenkoski, and participants at the 2011 International Perspectives on Time Use Conference at the University of Maryland and 2014 Society of Labor Economists' Annual Meeting for useful suggestions.
} 


\section{Introduction}

Job losses during and after the Great Recession of 2008-09 have had a tremendous impact on the health and incomes of a large number of Americans. Although numerous papers have examined the total economy-wide effects of the Great Recession on adults and families, none has specifically focused on effects of the Great Recession on the health and human capital investments made by teenagers aged 15-17, an especially vulnerable segment of the population. Teenagers may be affected by changes in macroeconomic conditions through numerous channels, including by direct changes to their own labor demand and future employment expectations, and by the stress resulting from the job losses experienced by their parents or the parents of their classmates (Ananat et al., 2012; Arkes and Klerman, 2009; Bell and Blanchflower, 2011). The direction of the total effects of the economy on teenagers' risky behaviors and time use is ambiguous (Arkes and Klerman, 2009).

A number of studies have found that during previous economic downturns, some teenagers engaged more than usual in risky health behaviors such as substance abuse and sexual activity (Arkes, 2007; Arkes and Klerman, 2009; Levine, 2001). Arkes (2009) also found changes in teenage weight over the cycle, with male teenagers losing weight and female teenagers gaining weight in weaker economic periods. However, these researchers lacked time diary data to examine some of the potential explanations, for example changes in parental supervision, for these changes in behavior over the business cycle. Even though parents may lose their jobs in a recession or have their hours cut, this does not necessarily mean that they will spend more time with their children, because their children are in school during the majority of the hours parents would typically be working. In fact, Morrill and Pabilonia (2012) found that mothers, who are still the primary childcare providers in the U.S., work more hours on the 
weekends as the state-level unemployment rate increases, suggesting that parental supervision on weekends could fall. Aizer (2004) has documented that children aged 10-14 who are left unsupervised after school may engage more in risky behaviors such as skipping school, using alcohol or drugs, stealing something, or hurting someone. In addition, family members may choose to spend less time together if they are stressed or depressed due to financial difficulties.

The goals of this paper are to 1) provide a description of the total effects of the economy on teenagers' risky health behaviors during the most recent recession, 2) examine several hypotheses about the potential reasons for these changes in behavior, including changes in the time teenagers spend being supervised by their parents, changes in time spent working, and changes in sports participation, and 3) describe other effects that the Great Recession has had on teenagers' other major uses of time, especially effects related to investments in schooling-related human capital, which may affect the future earnings of this new cohort just beginning to enter the labor market. This paper uses state-level unemployment rates to proxy for macroeconomic conditions in order to examine the total effects of the economy on teenagers' activities. Results indicate that the effects vary by both gender and race/ethnicity. Hispanic male teenagers engage more in sexual activity during poorer economic conditions, while black male teenagers engage less in sexual activity. These patterns are consistent with changes in parental supervision over the business cycle, with Hispanic male teenagers spending less time with a parent in weaker economic conditions and black male teenagers spending more time with at least one of their parents. Also, consistent with a decrease in parental supervision, Hispanic male teenagers were more likely to have drunk alcohol in the past 30 days when the unemployment rate was higher. At the same time, teenage girls were not any more or less likely to spend time with their parents over the business cycle, but they did spend less time working during the recession. Hispanic 
female teenagers spent more time on educational activities, and all females significantly decreased their TV viewing, both changes of potential benefit for future outcomes. However, teenage girls also slept less and smoked more regularly.

\section{Data and Descriptive Statistics}

This paper primarily uses two pooled cross-sectional data sets covering the period from 2003 to 2011: the Centers for Disease Control and Prevention’s (CDC) National Youth Risk Behavior Survey (YRBS) and the Bureau of Labor Statistics' (BLS) American Time Use Survey (ATUS). In addition, I supplement information on youths' behaviors with information on state laws and state-level unemployment rates that may affect teenagers' activities. I describe each of these sources of data in more detail below.

\subsection{YRBS}

In 1991, the YRBS began interviewing high school students biannually. Data are available through 2011. Thus, it is unique in providing information on teenagers' risky behaviors before and through the Great Recession. I focus on high school students aged 15-17 during the period of time that matches the ATUS collection period (2003-2011), as I want to examine possible explanations for the effects of changing state-level economic conditions on risky behaviors. The upper age limit is 17 because many youths older than this have graduated from high school and may be living away from their parents. (However, I include estimates for all high school students and the entire sample period in the Appendix. $)^{1}$ Almost all students

\footnotetext{
${ }^{1}$ Height and weight were not reported before 1999. Therefore, it is only possible to examine the effects of changes in economic conditions on the probability of being overweight or obese from 1999-2011.
} 
were interviewed between January and June. One of the drawbacks of the survey compared to other surveys capturing information on risky behaviors, such as the NSLY97, is the limited demographic information collected. The YRBS collects individual-level information such as age and grade in school as well as race and ethnicity, but no information about the teens' parents or siblings. However, many of the results are similar to those found using the NLSY97. The YRBS also cannot capture the effects of changes in state-level economic conditions on risky behaviors that may operate through changes in school enrollment. State indicators are available upon request from the CDC. Therefore, I can control for state-level economic conditions as well as specific state laws that may affect teenagers' activities. Even though weights are available that when applied make this survey nationally representative of $9^{\text {th }}$ through $12^{\text {th }}$ graders, not all states were surveyed. From 2003 to 2011, there were respondents in 13 states in all survey years, respondents in 4 states for 4 of the survey years, respondents in 8 states for 3 of the survey years, respondents in 11 states for 2 of the survey years, and respondents in 7 states for only one of the survey years.

The YRBS sample of high school students aged 15-17 includes 27,894 males and 26,770 females. More details on the sample selection can be located in Appendix Table A1. Table I shows the weighted percentage of high school students participating in various risky behaviors each year, by gender, and by race/ethnicity subgroups within gender groups. The table covers three basic groupings of health-risk behaviors: sexual activity, drug and alcohol use, and carrying excessive weight. From 2003 to 2011, teenage sexual activity in the three months preceding the survey fell slightly overall, with most of the decrease occurring among black and Hispanic youths. However, contraceptive use at last intercourse also fell, more dramatically so for teenage girls. Smoking and alcohol use also fell over the period, again most dramatically for females. 
Marijuana use did not follow any specific trend over the period. Finally, the percentage of teens considered overweight or obese was slightly lower during the recession and its aftermath (20092011) than during the preceding expansion from 2005-2007. In all years, non-Hispanic black females were much more likely to be overweight or obese than their peers, while Hispanic males were more likely to be overweight or obese than their peers. ${ }^{2}$

\subsection{ATUS}

This paper uses all data currently available from the nationally representative crosssectional American Time Use Survey (ATUS) - 2003-2011. This time use survey is unique in that it is an ongoing survey of individuals aged 15 and older and thus now well suited for examining the effects of the Great Recession on time use. Individuals may be interviewed any day of the year, except for the day before major holidays. Respondents are randomly selected from households from a subset of households that have completed their final interview for the Current Population Survey (CPS).

The ATUS updates some information from the CPS as well as collecting a 24-hour diary that begins at 4 P.M. the day prior to the interview. Respondents are asked to sequentially list their activities as well as where the activity took place and, for most activities, who was in the room with them if they were at home or who accompanied them on an activity if they were away from home ("with whom" information was not collected for times when the respondent reported sleeping, grooming, private activities, refused to classify type or can’t remember, and working, the last category only prior to 2010). The response rate exceeded 53 percent in each year.

\footnotetext{
${ }^{2}$ Height and weight were self-reported by students. Overweight is defined as greater than or equal to $85 \%$ on the body-mass-index (BMI) percentile chart based upon age and gender. Obese is defined as greater than or equal to $95 \%$ on the BMI percentile chart based upon age and gender.
} 
Approximately half of diaries were recorded for weekdays and the other half for weekend days. ATUS final weights, reweighted for equal day of the week representation for the male and female teen subsamples separately, are used in all analyses. Estimates from time diaries of time spent on activities are thought to be more accurate than those from usual retrospective questions, as they are less subject to aggregation bias, recall bias, and social desirability bias (Bianchi et al., 2006).

The ATUS sample includes 1,974 boys and 2,146 girls who were aged 15-17, lived with at least one parent, and were interviewed during the school year. ${ }^{3}$ Youths in all family structures and both enrolled and non-enrolled students are included in the sample in order to measure the total effects of the economy on the time use of all teenagers. Appendix Table A5 explains the sample selection criteria. All analyses in the paper are done separately for boys and girls, given the large differences in time they spend on some activities, the types of jobs they hold, and increasing differences in educational outcomes between the sexes.

\section{Measures of Time Use}

The outcome I examine is either the number of minutes a teen spends on an activity or, in the case of work, whether the teen was employed or worked on the diary day. In most cases, the time a teen spends doing the activity is measured from minutes spent on activities during the 24hour diary day. However, the ATUS diary also includes the end time of the last activity that was recorded in the diary. Usually, the respondent's last activity was sleeping; thus, it is possible to also construct a measure of the full night time sleep episode following the diary day. I first examine the time a teen spends with either parent, one potential measure of the level of parental

\footnotetext{
${ }^{3}$ Youths interviewed from Memorial Day through Labor Day are excluded from the sample, because many teenagers are on summer vacation.
} 
supervision. I also consider the total time a teen spends with his or her mother and then the total time a teen spends with his or her father. A reduction in a teenager's time spent with parents may be detrimental, both because time spent unsupervised may be used for engaging in counterproductive or risky behaviors and because time with parents may be positively associated with cognitive and social development. Then, I examine the time and timing of teens' paid work. Finally, I examine other major activities that teens spend time on, including various educational activities, sports, sleep, watching television and playing computer games, household work, and general leisure, which may affect their current and future well-being.

\subsection{Macroeconomic Conditions}

The main independent variable used in the analysis is the state yearly unemployment rate, a standard proxy for macroeconomic conditions. The state yearly unemployment rate is created from monthly and annual data obtained from the BLS' Local Area Unemployment Statistics (LAUS) database. It is measured as either the average of the last 12 monthly unemployment rates, ending with the interview month when using the ATUS, or the previous year's annual unemployment rate when using the YRBS. A yearly rate is used instead of a shorter rate to smooth some of the volatility in the CPS estimate (Arkes and Klerman, 2009; Morrill and Pabilonia, 2012). ${ }^{4}$ The overall economy rate is used as opposed to a teenage rate because the goal of the paper is to examine how teenagers' behaviors change with an exogenous shock and not just how teenagers respond to changes in their own labor demand. In addition, although the teen unemployment rate moves together with the overall unemployment rate, it is definitely more

\footnotetext{
${ }^{4}$ However, a three-month rate produced similar estimates.
} 
volatile and not an official BLS publication at the state level because of the increased sampling error.

\subsection{State Laws}

In all regressions, I also control for the effects of state and federal minimum wage laws, the state maximum compulsory schooling age, and the state minimum age to obtain a driver's license. The minimum wage is the natural logarithm of the higher of the federal or state

minimum wage in each state. ${ }^{5}$ Using the ATUS, Song (2012) found that higher minimum wages decrease teen employment and increase teen enrollment and time spent on education. The magnitude of these effects varied with the legal dropout age. Thus, I also include the state maximum compulsory schooling age, which ranged from 15 to 18 over the period. In addition, there were several increases during the period in the minimum age required to obtain a driver's license that would permit a student to drive legally to a place of employment without a parent present in the car, thus further decreasing student job opportunities at the time the recession hit (Pabilonia, 2001). Over the Great Recession, many states increased their cigarette taxes. In the smoking regressions, I include the real state cigarette price, which is measured as of November $1^{\text {st }}$ of the year prior to the survey year and is the weighted average cigarette price per package of twenty cigarettes for all brands including generics and including state and federal excise taxes as reported in the Tax Burden on Tobacco: Historical Compilation (Orzechowski and Walker, 2011).

\section{Estimation and Results}

${ }^{5}$ The wage was adjusted for inflation using the CPI-U/100 (base year 1982-84). 


\subsection{Risky Health Behaviors}

I first estimate the following series of linear probability models using Ordinary Least Squares (OLS):

$$
\mathrm{Y}_{\text {ist }}=\alpha+\beta \text { Urate }_{s,-1}+\mathrm{X}_{\text {ist }} \gamma+\eta \mathrm{Z}_{\text {st }}+\delta_{s}+\theta_{t}+\varepsilon_{\text {ist }}
$$

where $\mathrm{Y}_{\text {ist }}$ is an indicator equal to one if teen $i$, living in state $s$, participated in a risky behavior in survey year $t$ (where the length of time in which the behavior could occur varies by the behavior measured), $\delta$ 's and $\theta$ 's are state and year fixed effects respectively, Urate ${ }_{s, t-1}$ is the state-level unemployment rate in year $t-1, \mathrm{X}_{\text {ist }}$ is a vector of individual-level variables and $\mathrm{Z}_{\mathrm{st}}$ is a vector of state-level laws, $\varepsilon_{i s t}$ is a stochastic disturbance term assumed to follow a normal distribution. $\mathrm{X}_{\text {ist }}$ includes indicators for age, race and ethnicity (non-Hispanic black, Hispanic), and grade in school. $Z_{s t}$ includes the state maximum compulsory schooling age, the natural logarithm of the minimum wage, the state minimum age for getting an unrestricted driver's license. In the smoking models, I also include the real state cigarette price. The key coefficient of interest is $\beta$, the effect of the unemployment rate on a teen's probability of participating in a risky behavior, which captures the effect of within-state variation in economic conditions over time relative to other states. ${ }^{6}$ Sample means for all variables used in these regressions are in Appendix Table A2.

Table II presents the estimated coefficient $\beta$ using pooled cross-sectional data from the 2003-2011 YRBS, with separate estimates by gender, and then race/ethnicity subgroups by gender. For all regressions reported in the paper, robust standard errors are adjusted for clustering by state. The sample sizes for these analyses vary due to different nonresponse rates for the dependent variables.

${ }^{6}$ The year effects absorb the effects of the national business cycle. 
Hispanic male teenagers aged 15-17 are more likely to have engaged in sexual activity in the prior three months during weaker economic times as measured by the previous year's unemployment rate. For a one-percentage point increase in the unemployment rate, the probability of having sex increases by 1.8 percentage-points. Black male teenagers, on the other hand, are less likely to engage in sexual activity. For a one-percentage point increase in the unemployment rate, the probability of their having sex decreases by 2.6 percentage-points. These contradicting effects of the unemployment rate on the sexual activity of male teenagers by race/ethnicity are consistent with Arkes and Klerman’s (2009) findings for male teenagers during the late 1990s and early 2000s. However, I do not find any significant effects of the Great Recession on female teenagers' sexual behavior whereas Arkes and Klerman (2009) found evidence of counter-cyclical sexual activity among female teenagers.

Similar to Arkes (2007), I find a few statistically significant positive effects of weakening economic conditions upon drug and alcohol use. Hispanic male teenagers were 2.2 percentage points more likely to have drunk any alcohol in the last 30 days for each one-percentage-point increase in the unemployment rate. For each one-percentage-point increase in the unemployment rate, black male teenagers were 1.9 percentage points more likely to have used marijuana. Hispanic male teenagers were 1.2 percentage points more likely to have used marijuana, but the estimate was not significant at conventional levels. In the next section, I look for any evidence of changes in parental supervision that could explain these changes in sexual activity and drug and alcohol use over the business cycle. Even though regular smoking among teenagers has fallen each year over the period, I find that NBNH female teenagers were 0.9 percentage points more likely to have smoked every day in the past 30 days for each onepercentage-point increase in the unemployment rate. This is the only result showing an increase 
in risky behaviors among females during the recession. This finding is also consistent with recent evidence by Cheng and Kenkel (2010) that smoking has recently shifted from being a normal good to an inferior good.

Finally, I find that Hispanic male teenagers’ weight increased during the Great Recession. For a one-percentage-point increase in the unemployment rate, they were 1.7 percentage points more likely to be considered obese. There were no changes in female teenagers' weight. Thus, these results differ from Arkes' (2009) findings on changes in teenage weight in the previous recession, although he did not present separate estimates by race and ethnicity. In the next section, I look for any evidence of changes in time use, such as a corresponding decrease in physical activity or increase in TV-watching, which could help to explain this change in weight. ${ }^{7}$

Results for all high school students aged 12-18 are shown in Appendix Table A3. Results for the entire YRBS sampling period (1991-2011) are shown in Appendix Table A4. Among all high school students, I do not find statistically significant changes in male teenagers' participation in sexual activity over the business cycle, although NBNH male teenagers were less likely to use contraceptives if they engaged in sexual intercourse when the unemployment rate increased. I find similar effects of the unemployment rate on drug and alcohol use and the effect of the unemployment rate on marijuana use is not significant for Hispanic males (Table A3). There are no significant effects of the unemployment rate on teenagers' weight. Over all years (1991-2011), I find that Hispanic male teenagers' sexual activity is counter-cyclical (Table A4). In addition, black and Hispanic male teenagers' alcohol and drug use is counter-cyclical. NBNH

\footnotetext{
${ }^{7}$ Physical activity could change because of changes in recreational sports or work-related exertion over the business cycle. For example, Colman and Dave (2013) found that among loweducated adult males, total physical exertion declined as work-related exertion due to job-loss decreased more than recreational sports, TV-watching, sleeping, childcare, and housework increased during the Great Recession.
} 
male teenagers were less likely to be obese when the unemployment rate increased in the prior recession, as found by Arkes (2009).

\subsection{Teenage Time Use}

Using data from the ATUS, I estimate the following model using $\mathrm{OLS}^{8}$ :

$$
\text { Time }_{i s t}=\alpha+\beta \text { Urate }_{s, t-1}+\gamma \mathrm{X}_{\text {ist }}+\eta \mathrm{Z}_{\text {st }}+\delta_{s}+\theta_{t}+\varepsilon_{\text {ist }}
$$

where Time ist $_{\text {is }}$ the number of minutes per day that teen $i$ spends on various activities, living in state $s$, at time $t$; Urate $_{s, t-1}$ is the state-level unemployment rate averaged over the last twelve months (t-1), $\mathrm{X}_{\text {ist }}$ is a vector of observable individual and family-level variables, $\mathrm{Z}_{\mathrm{st}}$ is a vector of state-level laws, $\alpha$ is a constant, $\delta$ 's are state fixed effects, and $\theta$ 's are year fixed effects. $\varepsilon_{\text {ist }}$ is a stochastic disturbance term assumed to follow a normal distribution. The key coefficient of interest is $\beta$, the effect of the unemployment rate on a teen's time use. $X_{\text {ist }}$ includes mother's and father's age and age squared, and indicators for age, mother's and father's education level (high school dropout, some college, college, missing), race and ethnicity (non-Hispanic black, other, Hispanic), $1^{\text {st }}$ or $2^{\text {nd }}$ generation immigrant, family structure (living with single mom, living with single dad), age of youngest household child (infant, preschooler, elementary), number of household children (two, three or more), household child older than age 18, lives with other adults, gender composition of the children (all boy, mixed gender), season, and respondent lives in SMSA. These controls are included based upon the previous literature on teenagers' time use derived from the ATUS, including Porterfield and Winkler (2007), Wight et al. (2009), Kofman and Bianchi (2012), and Kalenkoski and Pabilonia (2012). $Z_{s t}$ includes the log of the state

\footnotetext{
${ }^{8}$ When examining the probability of being employed or working on the diary day, I estimate linear probability models.
} 
minimum wage, state minimum driving license age, state maximum compulsory schooling age. Appendix Table A6 shows the means for the variables used in the time use analyses.

I first examine the effects of the economy on the total time spent by a teenager in the presence of at least one parent (one measure of parental supervision) as being a potential explanation for the previously observed changes in the probability of participating in risky health behaviors over the business cycle. ${ }^{9}$ Table III shows that teenage boys spent on average 7 minutes less per day with a parent for each one-percentage-point increase in the unemployment rate. ${ }^{10}$ Over the Great Recession, the unemployment rate rose on average 5 percentage points; thus, this is a meaningful decrease in parental supervision as the economy weakened. Effects for non-black teenage boys were larger (10-11 minutes less per day) while non-Hispanic blacks spent more time with a parent (9 minutes more per day); but the estimates are imprecise due to smaller sample sizes. These differences in time spent by race/ethnicity correspond to the differences found in Table II in male teenagers' patterns of sexual activity over the business cycle. It is possible that these results differ by race/ethnicity because the Great Recession disproportionately affected the unemployment rate of black adults, potentially giving them more time for parental supervision (U.S. Department of Labor 2012). The time that male teenagers spend with parents also appears to fall most on non-school days and among the employed as the unemployment rate rises. It is possible that these effects result from changes in the timing of work that could make it more difficult for families to coordinate joint activities. I do not find any statistically significant differences in the time female teenagers spend with a parent over the

\footnotetext{
${ }^{9}$ The ATUS only collects secondary childcare time for children under the age of 13 . I also examined an alternative measure as the sum of both parents' time with children (as suggested in Folbre et al., 2005), with similar results.

${ }^{10}$ Estimates for all the covariates are in Appendix Table A7.
} 
business cycle (Table III), which is consistent with the findings in Table II that for females there were no changes in risky behaviors that are more likely to occur when a parent is not present.

I next examine the effects of the state-level unemployment rate on the time and timing of teenage paid work by gender (Table IV). It is not possible to consider all the effects of the unemployment rate on minutes worked by race/ethnicity, given the small sample sizes; however, Hispanic female teenagers work fewer minutes and are less likely to work on a weekday when the unemployment rate increases (estimates available upon request). Teenagers were not any less likely to be employed as the state unemployment rate increased over the recent recession when I controlled for other covariates; however, girls work significantly fewer minutes per day when state unemployment rates are higher. This negative effect of the unemployment rate on minutes worked is concentrated on weekdays. These gender differences in minutes worked may be due to the types of jobs that teens hold. In Table V, I show that employed girls are much more likely to babysit (i.e. childcare worker) or do sales work than are employed boys. Boys are more likely to hold maintenance jobs. The hours on these jobs may have been differently affected by the recession. For example, it may have been easier for families to cut back on babysitting hours. In addition, I note that a higher percentage of employed girls held a sales job after the financial crisis than in years before the crisis while a smaller percentage babysat or held a maintenance position.

I also consider the time teenagers spend with their mothers separately from the time they spend with their fathers. Results in Table VI indicate that teenage boys spend significantly less time with their mothers when the unemployment rate increases, which may account for the reduction in total parental supervision, because much of the time that fathers spend with their children is time that they also spend with the mother. This is consistent with Morrill and 
Pabilonia’s (2012) finding that mothers in two-parent families were more likely to work on weekend days when the unemployment rate was relatively high, which may also explain why results for total parental supervision were stronger on non-school days. One reason that I do not find similar results in Table VII for teenage girls may be that mothers usually spend more time, on average, with teenage daughters than with teenage sons (126 minutes versus 90 minutes). This could be either because mothers prefer spending time with daughters or because daughters need more developmental time with mothers, making it a priority (Lundberg et al., 2008).

Finally, I examine teenagers' other major uses of time: school-related activities, sports, sleep, and screen time (e.g. TV and video games). ${ }^{11}$ I find that male teenagers play sports less and sleep more at night when the unemployment rate increases (Table VI). The former effect could be related to the costs of participating in high school sports [or club sports] because schools increased afterschool sports fees and even eliminated some sports programs during the recession (Garcia, 2009). When I examine the changes in sports by race/ethnicity, I find that as the unemployment rate increases, it is black and Hispanic youths who play sports less. Thus, this is one potential explanation for the weight gained by Hispanic males over the business cycle.

Hispanic female teenagers are much more likely to be enrolled in school at higher unemployment rates (Table VII), which is consistent with their being less likely to be working on weekdays at higher unemployment rates. However, the net effect of the recession on the future wage returns to Hispanic female teenagers' human capital investments (i.e., educational attainment minus the loss in job experience) is unknown, as the literature on the returns to early job experience suggests positive effects on wages (Stephenson, 1981; Michael and Tuma, 1984;

\footnotetext{
${ }^{11}$ I also examined housework; but teens do little housework, and all the effects were insignificant.
} 
Ruhm, 1995, 1997; Light, 1999, 2001; Neumark and Joyce, 2001). Females also spent less time sleeping and less time watching TV.

\section{Conclusion}

The Great Recession of 2008-09 has had significant effects on the activities of today's youths that have a potential to affect their future health and economic opportunities in both positive and negative directions. Most significantly, Hispanic male teenagers increased their sexual activity and spent less time with their parents, while black male teenagers decreased their sexual activity and spent more time with their parents. The heterogeneous effects of the recession on parental supervision potentially explain why black and Hispanic male teenagers' sexual behavior differs during recessions. In addition, it could explain why Hispanic male teenagers were more likely to have drunk alcohol in the past 30 days. However, changes in parental supervision cannot explain why black male teenagers are more likely to smoke marijuana. This effect could potentially result because there are more teenage drug sellers in a weak economy as other job opportunities dry up, thus increasing teenagers' access to drugs during hard economic times, and potentially counteracting any positive effects of increased parental supervision for blacks in a weak economy (Arkes, 2007). Both results are also consistent with black communities being harder hit during the Great Recession. Hispanic male teenagers gained weight during the Great Recession, which is consistent with their decrease in sports participation.

Hispanic female teenagers shifted their time toward educational activities as opportunities for employment shrank. All female teenagers significantly decreased their TV watching. 
However, there are still signs that female teenagers were stressed, because they slept less and were more likely to smoke regularly during the most recent recession. 


\section{References}

Aizer A. 2004. Home Alone: Supervision After School and Child Behavior. Journal of Public Economics 88: 1835-48.

Ananat E, Gassman-Pines A, Francis D, Gibson-Davis C. 2011. Children Left Behind: The Effects of Statewide Job Loss on Student Achievement. NBER Working Paper No. 17104.

Arkes J. 2007. Does the Economy Affect Teenage Drug Use? Health Economics 16: 19-36.

Arkes J. 2009. How the Economy Affects Teenage Weight. Social Science \& Medicine 68: 1943-1947.

Arkes J, Klerman J. 2009. Understanding the Link Between the Economy and Teenage Sexual Behavior and Fertility Outcomes. Journal of Population Economics 22: 517-536.

Bell D, Blanchflower D. 2011. Young People and the Great Recession. Oxford Review Economic Policy 27(2): 241-267.

Bianchi S, Robinson J, Milkie M. 2006. Changing Rhythms of American Family Life. Russell Sage, New York.

Cheng K, Kenkel D. 2010. U.S. Cigarette Demand: 1944-2004. The B.E. Journal of Economic Analysis \& Policy 10(1).

Colman G, Dave D. 2011. Exercise, Physical Activity, and Exertion over the Business Cycle. Social Science \& Medicine 93: 11-20.

Folbre N, Finnoff Y, Fuligni A. 2005. By What Measure? Family Time Devoted to Children in the United States. Demography 42(2): 373-390.

Garcia M. 2009. At Some Schools, Budget Cuts put the Kibosh on Sports. USA Today, 2 September. <http://usatoday30.usatoday.com/sports/preps/2009-09-02budget_sports_cuts_N.htm>

Kalenkoski C, Pabilonia S. 2012. Time to Work or Time to Play: The Effect of Student Employment on Homework, Sleep, and Screen Time. Labour Economics 19: 211-21.

Levine P. 2001. The Sexual Activity and Birth-control Use of American Teenagers. In: Gruber, J (ed), Risky Behavior Among Youths: An Economic Analysis. University of Chicago Press, Chicago: 167-217.

Light A. 1999. High School Employment, High School Curriculum, and Post-School Wages. Economics of Education Review 18(3): 291-309. 
Light A. 2001. In-school Work Experience and the Returns to Schooling. Journal of Labor Economics 19(1): 65-93.

Kofman Y, Bianchi S. 2012. Time Use of Youths by Immigrant and Native-born Parents: ATUS Results. Monthly Labor Review 135(7): 3-24.

Lundberg S, Pabilonia S, Ward-Batts J. 2008. Time Allocation of Parents and Investments in Sons and Daughters. Mimeo.

Michael R, Tuma N. 1984. Youth Employment: Does Life Begin at 16? Journal of Labor Economics 2(4): 464-476.

Morrill M, Pabilonia S. 2012. What Effects do Macroeconomic Conditions Have on Families' Time Together? IZA Working Paper No. 6529.

Pabilonia S. 2001. Youth Employment and Parental Transfers. Ph.D. Dissertation, University of Washington.

Porterfield S, Winkler A. 2007. Teen Time Use and Parental Education: Evidence from the CPS, MTF, and ATUS. Monthly Labor Review 130(5): 37-56.

Ruhm C. 1995. The Extent and Consequences of High School Employment. Journal of Labor Research 16(3): 293-304.

Ruhm C. 1997. Is High School Employment Consumption or Investment? Journal of Labor Economics 15(4): 735-776.

Ruhm C. 2000. Are Recessions Good for Your Health? Quarterly Journal of Economics 115: 617-650.

Song Y. 2012. Minimum Wages and Teen Time Use. Mimeo.

Stephenson S. 1981. In-school Labour Force Status and Post-school Wage Rates of Young Men. Applied Economics 13(3): 279-302.

Orzechowski and Walker. 2011. The Tax Burden on Tobacco: Historical Compilation. 46 Arlington, VA: Orzechowski and Walker.

Wight V, Price J, Bianchi S, Hunt B. 2009. The Time Use of Teenagers. Social Science Research 38(4): 792-809.

U.S. Department of Labor. 2012. The African-American Labor Force in the Recovery. <http://www.dol.gov/_sec/media/reports/BlackLaborForce/BlackLaborForce.pdf>, Accessed November 2, 2012. 


\begin{tabular}{|c|c|c|c|c|c|c|c|c|c|c|}
\hline & \multicolumn{5}{|c|}{ Boys } & \multicolumn{5}{|c|}{ Girls } \\
\hline & 2003 & 2005 & 2007 & 2009 & 2011 & 2003 & 2005 & 2007 & 2009 & 2011 \\
\hline & \multicolumn{10}{|c|}{ SEXUAL ACTIVITY IN PAST THREE MONTHS } \\
\hline ALL & 33.7 & 31.6 & 33.7 & 32.4 & 32.4 & 35.5 & 34.5 & 35.5 & 35.5 & 34.9 \\
\hline $\mathrm{NBNH}$ & 28.9 & 27.7 & 28.7 & 28.7 & 29.6 & 33.6 & 33.0 & 34.0 & 34.1 & 34.8 \\
\hline Non-Hispanic Black & 53.8 & 50.5 & 48.6 & 49.0 & 44.5 & 43.8 & 43.0 & 43.0 & 45.0 & 37.2 \\
\hline \multirow[t]{2}{*}{ Hispanic } & 39.3 & 35.1 & 41.1 & 35.5 & 34.3 & 37.0 & 34.0 & 34.5 & 33.3 & 33.8 \\
\hline & \multicolumn{10}{|c|}{$\begin{array}{l}\text { CONTRACEPTIVE USE AT LAST INTERCOURSE IN PAST THREE } \\
\text { MONTHS }\end{array}$} \\
\hline ALL & 89.6 & 88.6 & 89.0 & 89.7 & 88.7 & 87.6 & 85.5 & 86.7 & 86.2 & 84.6 \\
\hline $\mathrm{NBNH}$ & 92.4 & 88.7 & 90.6 & 92.6 & 89.9 & 90.8 & 88.3 & 89.3 & 90.4 & 87.2 \\
\hline Non-Hispanic Black & 91.0 & 90.0 & 89.2 & 87.6 & 89.9 & 87.5 & 81.9 & 84.4 & 80.2 & 84.2 \\
\hline \multirow[t]{2}{*}{ Hispanic } & 79.3 & 86.3 & 84.0 & 82.6 & 83.8 & 76.0 & 76.4 & 79.1 & 76.7 & 75.5 \\
\hline & \multicolumn{10}{|c|}{ SMOKE IN PAST 30 DAYS } \\
\hline ALL & 21.5 & 22.6 & 21.7 & 19.0 & 18.5 & 22.6 & 23.6 & 18.7 & 19.3 & 16.3 \\
\hline $\mathrm{NBNH}$ & 22.4 & 23.7 & 22.7 & 20.6 & 19.9 & 26.2 & 26.6 & 21.8 & 22.4 & 18.5 \\
\hline Non-Hispanic Black & 18.8 & 14.7 & 14.1 & 11.3 & 13.5 & 10.6 & 12.5 & 8.2 & 8.9 & 6.9 \\
\hline \multirow[t]{2}{*}{ Hispanic } & 19.4 & 24.6 & 18.4 & 18.8 & 16.8 & 17.4 & 20.4 & 15.7 & 16.5 & 15.7 \\
\hline & \multicolumn{10}{|c|}{ SMOKE DAILY IN PAST 30 DAYS } \\
\hline ALL & 7.4 & 6.9 & 5.8 & 5.1 & 4.4 & 7.7 & 7.0 & 5.7 & 4.4 & 4.0 \\
\hline NBNH & 8.2 & 7.9 & 7.1 & 6.2 & 5.1 & 9.8 & 8.6 & 7.7 & 5.9 & 5.2 \\
\hline Non-Hispanic Black & 6.5 & 4.1 & 3.2 & 2.2 & 2.5 & 2.0 & 2.0 & 0.8 & 0.7 & 1.5 \\
\hline \multirow[t]{2}{*}{ Hispanic } & 4.6 & 5.0 & 2.8 & 3.4 & 3.2 & 3.4 & 4.3 & 2.0 & 1.9 & 1.5 \\
\hline & \multicolumn{10}{|c|}{ ALCOHOL USE IN PAST 30 DAYS } \\
\hline ALL & 43.8 & 43.8 & 44.8 & 41.2 & 38.7 & 46.4 & 43.3 & 44.3 & 43.0 & 38.6 \\
\hline $\mathrm{NBNH}$ & 45.0 & 45.2 & 46.5 & 42.4 & 40.0 & 47.6 & 44.9 & 45.4 & 44.6 & 38.2 \\
\hline Non-Hispanic Black & 36.9 & 30.4 & 33.1 & 30.4 & 28.2 & 37.8 & 33.3 & 34.0 & 35.9 & 32.6 \\
\hline \multirow[t]{2}{*}{ Hispanic } & 44.1 & 49.1 & 47.7 & 44.6 & 41.2 & 48.4 & 45.4 & 48.9 & 42.9 & 44.5 \\
\hline & \multicolumn{10}{|c|}{ MARIJUANA USE IN PAST 30 DAYS } \\
\hline ALL & 25.6 & 22.2 & 22.6 & 23.8 & 25.8 & 19.7 & 18.8 & 17.3 & 18.7 & 20.8 \\
\hline NBNH & 24.1 & 21.0 & 22.4 & 23.0 & 24.8 & 19.7 & 18.7 & 17.6 & 18.9 & 19.9 \\
\hline Non-Hispanic Black & 29.0 & 23.1 & 26.5 & 25.2 & 30.1 & 18.6 & 19.6 & 16.7 & 17.6 & 22.2 \\
\hline Hispanic & 29.6 & 27.3 & 20.2 & 25.9 & 26.5 & 20.6 & 18.0 & 16.6 & 18.6 & 22.3 \\
\hline
\end{tabular}

Notes: YRBS weights used. Race and ethnicity are mutually exclusive. 


\begin{tabular}{|c|c|c|c|c|c|c|c|c|c|c|}
\hline \multicolumn{11}{|c|}{$\begin{array}{l}\text { Table } 1 \text { Continued. Percentage of Teenagers Aged 15-17 Participating in Risky Behaviors } \\
\text { (Youth Risk Behavior Survey) }\end{array}$} \\
\hline & \multicolumn{5}{|c|}{ Boys } & \multicolumn{5}{|c|}{ Girls } \\
\hline & 2003 & 2005 & 2007 & 2009 & 2011 & 2003 & 2005 & 2007 & 2009 & 2011 \\
\hline & \multicolumn{10}{|c|}{ OVERWEIGHT (BMI>=85\%, by age and sex) } \\
\hline ALL & 30.7 & 33.2 & 33.7 & 31.2 & 31.3 & 22.5 & 25.7 & 25.5 & 24.3 & 24.6 \\
\hline NBNH & 28.0 & 32.2 & 31.6 & 28.0 & 30.1 & 18.9 & 22.3 & 20.9 & 19.9 & 21.1 \\
\hline Non-Hispanic Black & 33.9 & 32.3 & 37.3 & 37.8 & 30.5 & 35.3 & 39.1 & 40.1 & 35.2 & 38.9 \\
\hline \multirow[t]{2}{*}{ Hispanic } & 40.3 & 38.8 & 39.6 & 38.8 & 35.8 & 26.8 & 28.9 & 31.0 & 31.0 & 26.4 \\
\hline & \multicolumn{10}{|c|}{ OBESE (BMI $>=95 \%$, by age and sex) } \\
\hline ALL & 15.5 & 17.9 & 17.1 & 15.5 & 16.7 & 8.0 & 11.0 & 10.4 & 9.1 & 9.5 \\
\hline NBNH & 14.1 & 16.8 & 15.3 & 13.7 & 15.8 & 6.2 & 9.2 & 7.3 & 7.2 & 7.8 \\
\hline Non-Hispanic Black & 17.7 & 17.9 & 19.7 & 19.4 & 17.5 & 13.7 & 17.3 & 20.9 & 15.0 & 19.1 \\
\hline Hispanic & 19.5 & 23.1 & 22.1 & 19.5 & 19.1 & 11.0 & 13.1 & 13.5 & 11.5 & 8.6 \\
\hline
\end{tabular}

Notes: YRBS weights used. Race and ethnicity are mutually exclusive. 
Table II. Effects of the Unemployment Rate on Teen Risky Behaviors for Teens Aged 15-17, by Gender and Race/Ethnicity (YBRS 2003-2011)

\begin{tabular}{|c|c|c|c|c|c|c|c|c|}
\hline Subsample & $\begin{array}{c}\text { Sexual } \\
\text { Intercourse in } \\
\text { Past Three } \\
\text { Months }\end{array}$ & $\begin{array}{l}\text { Contraceptive } \\
\text { Use if Sexual } \\
\text { Intercourse }\end{array}$ & $\begin{array}{c}\text { Smoke in } \\
\text { Past } 30 \\
\text { Days }\end{array}$ & $\begin{array}{c}\text { Smoke Every } \\
\text { Day in Past } \\
30 \text { Days }\end{array}$ & $\begin{array}{c}\text { Alcohol Use } \\
\text { in Past } 30 \\
\text { Days }\end{array}$ & $\begin{array}{l}\text { Marijuana in } \\
\text { Past } 30 \text { Days }\end{array}$ & Overweight & Obese \\
\hline \multicolumn{9}{|c|}{ Panel 1. Boys } \\
\hline All & $\begin{array}{c}0.003 \\
(0.007)\end{array}$ & $\begin{array}{l}-0.008 \\
(0.007)\end{array}$ & $\begin{array}{c}0.008 \\
(0.008)\end{array}$ & $\begin{array}{c}0.004 \\
(0.004)\end{array}$ & $\begin{array}{c}0.007 \\
(0.009)\end{array}$ & $\begin{array}{c}0.002 \\
(0.008)\end{array}$ & $\begin{array}{c}0.005 \\
(0.007)\end{array}$ & $\begin{array}{c}0.005 \\
(0.005)\end{array}$ \\
\hline $\mathrm{NBNH}$ & $\begin{array}{c}0.009 \\
(0.010)\end{array}$ & $\begin{array}{c}-0.018 \\
(0.012)\end{array}$ & $\begin{array}{c}0.008 \\
(0.011)\end{array}$ & $\begin{array}{c}0.004 \\
(0.006)\end{array}$ & $\begin{array}{c}0.005 \\
(0.009)\end{array}$ & $\begin{array}{l}-0.009 \\
(0.009)\end{array}$ & $\begin{array}{c}0.009 \\
(0.010)\end{array}$ & $\begin{array}{c}0.003 \\
(0.006)\end{array}$ \\
\hline Black & $\begin{array}{c}-0.026 * \\
(0.015)\end{array}$ & $\begin{array}{c}0.012 \\
(0.014)\end{array}$ & $\begin{array}{c}0.014 \\
(0.015)\end{array}$ & $\begin{array}{c}0.008 \\
(0.006)\end{array}$ & $\begin{array}{l}-0.005 \\
(0.013)\end{array}$ & $\begin{array}{c}0.019 * * \\
(0.009)\end{array}$ & $\begin{array}{l}-0.018 \\
(0.013)\end{array}$ & $\begin{array}{c}0.009 \\
(0.009)\end{array}$ \\
\hline Hispanic & $\begin{array}{c}0.018 * * * \\
(0.006)\end{array}$ & $\begin{array}{c}0.004 \\
(0.012)\end{array}$ & $\begin{array}{c}0.012 \\
(0.008)\end{array}$ & $\begin{array}{l}-0.003 \\
(0.003)\end{array}$ & $\begin{array}{c}0.022 * * \\
(0.008)\end{array}$ & $\begin{array}{c}0.012 \\
(0.008)\end{array}$ & $\begin{array}{c}0.010 \\
(0.009)\end{array}$ & $\begin{array}{c}0.017 * * \\
(0.008)\end{array}$ \\
\hline $\mathrm{N}$ (All) & 24,000 & 8,077 & 25,295 & 25,295 & 24,377 & 25,981 & 25,270 & 25,270 \\
\hline \multicolumn{9}{|c|}{ Panel 2. Girls } \\
\hline All & $\begin{array}{c}0.002 \\
(0.010)\end{array}$ & $\begin{array}{l}-0.005 \\
(0.005)\end{array}$ & $\begin{array}{c}0.008 \\
(0.007)\end{array}$ & $\begin{array}{l}0.007 * * \\
(0.003)\end{array}$ & $\begin{array}{c}0.008 \\
(0.007)\end{array}$ & $\begin{array}{c}0.007 \\
(0.008)\end{array}$ & $\begin{array}{c}0.001 \\
(0.007)\end{array}$ & $\begin{array}{l}-0.001 \\
(0.004)\end{array}$ \\
\hline NBNH & $\begin{array}{c}0.009 \\
(0.013)\end{array}$ & $\begin{array}{c}-0.004 \\
(0.007)\end{array}$ & $\begin{array}{c}0.010 \\
(0.011)\end{array}$ & $\begin{array}{c}0.009 * * \\
(0.004)\end{array}$ & $\begin{array}{c}0.005 \\
(0.012)\end{array}$ & $\begin{array}{c}0.010 \\
(0.009)\end{array}$ & $\begin{array}{c}0.010 \\
(0.011)\end{array}$ & $\begin{array}{c}0.005 \\
(0.006)\end{array}$ \\
\hline Black & $\begin{array}{c}0.003 \\
(0.014)\end{array}$ & $\begin{array}{l}-0.005 \\
(0.019)\end{array}$ & $\begin{array}{l}-0.010 \\
(0.009)\end{array}$ & $\begin{array}{l}-0.001 \\
(0.004)\end{array}$ & $\begin{array}{c}0.018 \\
(0.011)\end{array}$ & $\begin{array}{l}-0.011 \\
(0.007)\end{array}$ & $\begin{array}{l}-0.003 \\
(0.016)\end{array}$ & $\begin{array}{l}-0.010 \\
(0.013)\end{array}$ \\
\hline Hispanic & $\begin{array}{c}-0.014 \\
(0.011)\end{array}$ & $\begin{array}{c}-0.004 \\
(0.011)\end{array}$ & $\begin{array}{c}0.006 \\
(0.009)\end{array}$ & $\begin{array}{c}0.006 \\
(0.004)\end{array}$ & $\begin{array}{c}-0.002 \\
(0.008)\end{array}$ & $\begin{array}{c}0.007 \\
(0.011)\end{array}$ & $\begin{array}{c}-0.011 \\
(0.009)\end{array}$ & $\begin{array}{c}0.002 \\
(0.004)\end{array}$ \\
\hline $\mathrm{N}($ All $)$ & 25,684 & 9,107 & 26,892 & 26,892 & 25,896 & 27,434 & 25,937 & 25,937 \\
\hline
\end{tabular}


Table III. Effects of the Unemployment Rate on Time with Either Parent (in minutes) for Teens Aged 15-17, by Gender (ATUS 2003-2011)

\begin{tabular}{|c|c|c|c|c|c|}
\hline Subsample & & $\mathbf{N}$ & Mean & Urate & $\mathbf{R}^{2}$ \\
\hline \multicolumn{6}{|l|}{ Panel 1. Teen Boys } \\
\hline All Boys & & 2,146 & 119.74 & $-7.425 *(3.911)$ & 0.069 \\
\hline \multirow[t]{3}{*}{ Race/Ethnicity } & $\mathrm{NBNH}$ & 1,554 & 131.97 & $-10.406(6.326)$ & 0.080 \\
\hline & Non-Hispanic Black & 233 & 79.15 & $9.370(14.350)$ & 0.314 \\
\hline & Hispanic & 359 & 112.14 & $-11.162(12.922)$ & 0.253 \\
\hline \multirow[t]{2}{*}{ Day of Week } & School day & 997 & 89.80 & $-2.219(4.036)$ & 0.132 \\
\hline & Non-school day & 1,149 & 188.10 & $-11.021(8.618)$ & 0.118 \\
\hline \multirow[t]{2}{*}{ Teens’ Earner Status } & Employed & 635 & 114.48 & $-12.702 *(7.381)$ & 0.212 \\
\hline & Not Employed & 1,511 & 121.77 & $-6.645(4.569)$ & 0.090 \\
\hline \multicolumn{6}{|l|}{ Panel 2. Teen Girls } \\
\hline All Girls & & 1,974 & 147.43 & $4.309(6.835)$ & 0.078 \\
\hline \multirow[t]{3}{*}{ Race/Ethnicity } & $\mathrm{NBNH}$ & 1,453 & 145.44 & $6.382(6.795)$ & 0.080 \\
\hline & Non-Hispanic Black & 204 & 116.61 & $-11.299(18.943)$ & 0.459 \\
\hline & Hispanic & 317 & 178.65 & $-6.536(18.566)$ & 0.240 \\
\hline \multirow[t]{2}{*}{ Day of Week } & School day & 937 & 111.90 & $-0.677(5.845)$ & 0.145 \\
\hline & Non-school day & 1,037 & 225.82 & 10.092(11.762) & 0.199 \\
\hline \multirow[t]{2}{*}{ Teens’ Earner Status } & Employed & 581 & 123.80 & $-8.751(11.215)$ & 0.196 \\
\hline & Not Employed & 1,393 & 156.24 & 7.312(8.330) & 0.088 \\
\hline
\end{tabular}

Standard errors adjusted for clustering by state are reported in parentheses. Control variables include mother and father's age and age squared, $\ln$ (minimum wage), state minimum driving license age, state maximum compulsory schooling age, and indicators for age, mother's and father's education level (high school dropout, some college, college, missing), family structure (single mother, single father), race and ethnicity (non-Hispanic black, Hispanic), $1^{\text {st }}$ or $2^{\text {nd }}$ generation immigrant, age of youngest household child (infant, preschooler, elementary), number of household children (two, three or more), household child older than age 18, lives with other adults, gender composition of the children (all boy, mixed gender), season, and respondent lives in SMSA. Significance levels: $* * *$ $\mathrm{p}<0.01 ; * * \mathrm{p}<0.05 ; * \mathrm{p}<0.10$. 
Table IV. Effects of the Unemployment Rate on Teenagers' Time and Timing of Work, by Gender (ATUS 2003-2011)

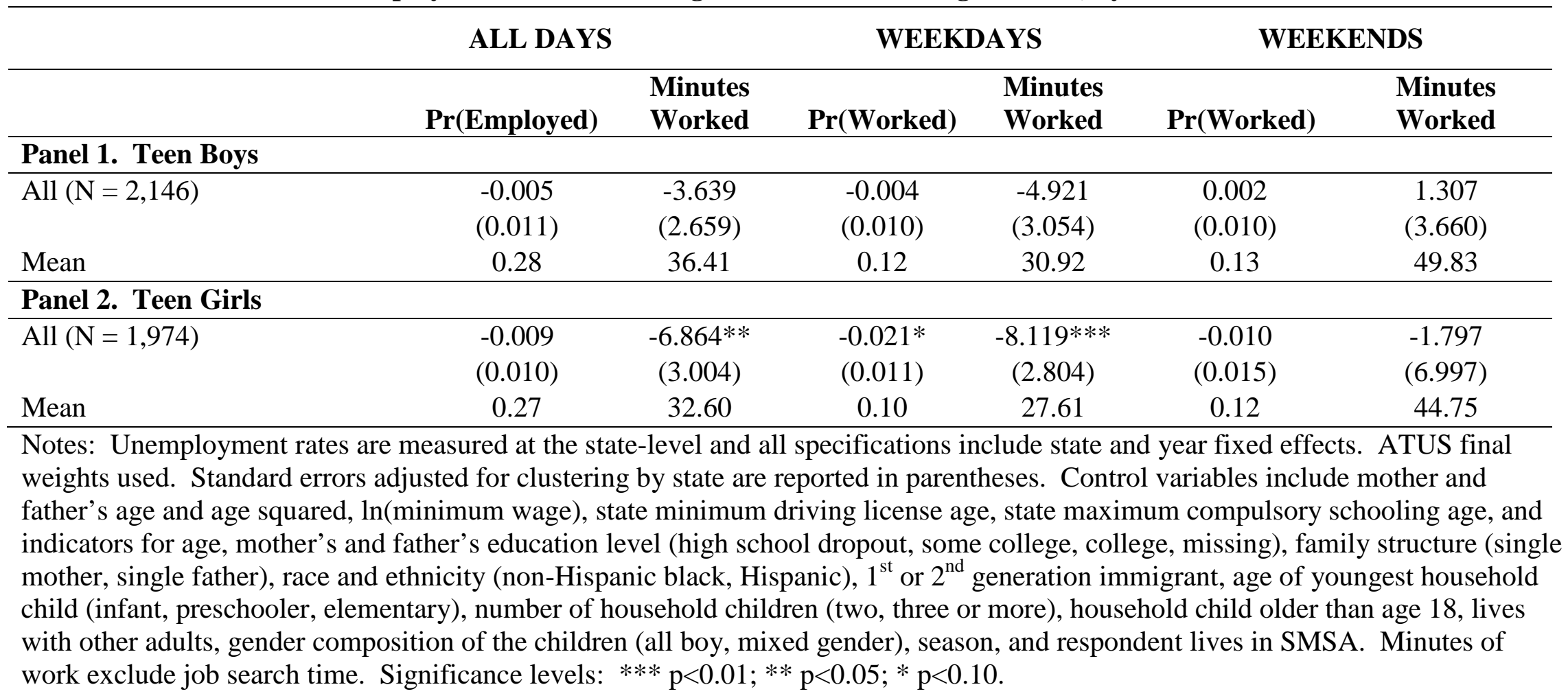


Table V. Top 8 Primary Jobs Held By Teens as a Percent of Those Holding Jobs, By Gender (ATUS 2003-2011)

\begin{tabular}{|c|c|c|c|c|c|c|}
\hline & \multicolumn{2}{|c|}{ 2003-2011 } & \multicolumn{2}{|c|}{ 2003-2007 } & \multicolumn{2}{|c|}{ 2008-2011 } \\
\hline & MALE & FEMALE & MALE & FEMALE & MALE & FEMALE \\
\hline Athletes, Coaches, Umpires, and Related Workers & 0.02 & 0.02 & 0.02 & 0.02 & 0.02 & 0.02 \\
\hline Food Preparation and Serving Related Occupations & 0.23 & 0.24 & 0.24 & 0.24 & 0.22 & 0.25 \\
\hline Building and Grounds Cleaning and Maintenance Occupations & 0.16 & 0.05 & 0.15 & 0.06 & 0.16 & 0.03 \\
\hline Childcare & 0.01 & 0.16 & 0.01 & 0.17 & 0.02 & 0.15 \\
\hline Sales and Related Occupations & 0.14 & 0.26 & 0.16 & 0.24 & 0.09 & 0.30 \\
\hline Stock Clerks and Order Fillers & 0.04 & 0.01 & 0.05 & 0.01 & 0.02 & 0.002 \\
\hline Miscellaneous Agricultural Workers & 0.04 & 0.02 & 0.03 & 0.02 & 0.04 & 0.02 \\
\hline Laborers and Freight, Stock and Material Movers & 0.07 & 0.01 & 0.05 & 0.01 & 0.09 & 0.01 \\
\hline Multiple Job Holders & 0.09 & 0.07 & 0.08 & 0.08 & 0.11 & 0.06 \\
\hline Number Employed & 635 & 581 & 433 & 400 & 202 & 181 \\
\hline
\end{tabular}

Notes: ATUS final weights used. Only the occupation of the primary job is recorded in the ATUS. 
Table VI. Effects of the Unemployment Rate on Teen Boys Aged 15-17 Time Use (ATUS 2003-2011)

\begin{tabular}{|c|c|c|c|}
\hline Dependent Variable & $\mathbf{N}$ & Mean & Urate \\
\hline Minutes with Mother & 2,146 & 89.58 & $-5.780 *(3.333)$ \\
\hline Minutes with Father & 2,146 & 74.50 & $-3.228(3.219)$ \\
\hline Minutes in Class & 2,146 & 219.01 & $3.672(6.186)$ \\
\hline Minutes of Homework & 2,146 & 40.82 & $-2.270(1.972)$ \\
\hline Minutes Homework \& Extracurricular Activities & 2,146 & 46.41 & $-2.580(2.960)$ \\
\hline Minutes of Total Education & 2,146 & 265.43 & $1.092(6.970)$ \\
\hline Minutes in Sports (All) & 2,146 & 53.42 & $-4.645 * *(2.000)$ \\
\hline NBNH & 1,554 & 52.52 & $-0.280(2.499)$ \\
\hline Non-Hispanic black & 233 & 66.07 & $-21.276 * *(9.093)$ \\
\hline Hispanic & 359 & 47.71 & $-12.126 *(6.173)$ \\
\hline Minutes Sleeping on Diary Day & 2,146 & 555.46 & $2.303(6.416)$ \\
\hline Minutes Sleeping on Night Following Diary Day & 2,146 & 516.77 & $7.492 * *(3.273)$ \\
\hline Minutes TV & 2,146 & 129.17 & $1.980(2.803)$ \\
\hline Minutes Games and TV & 2,146 & 196.49 & $5.457(5.223)$ \\
\hline \multicolumn{4}{|c|}{$\begin{array}{l}\text { Note: Unemployment rates are measured at the state-level and all specifications include state and year fixed effects. ATUS final } \\
\text { weights used. Standard errors adjusted for clustering by state are reported in parentheses. Control variables include mother and } \\
\text { father's age and age squared, ln(minimum wage), state minimum driving license age, state maximum compulsory schooling age, and } \\
\text { indicators for age, mother’s and father's education level (high school dropout, some college, college, missing), family structure (single } \\
\text { mother, single father), race and ethnicity (non-Hispanic black, Hispanic), } 1^{\text {st }} \text { or } 2^{\text {nd }} \text { generation immigrant, age of youngest household } \\
\text { child (infant, preschooler, elementary), number of household children (two, three or more), household child older than age } 18 \text {, lives } \\
\text { with other adults, gender composition of the children (all boy, mixed gender), season, and respondent lives in SMSA. Significance } \\
\text { levels: }{ }^{* * *} \mathrm{p}<0.01 ;{ }^{* *} \mathrm{p}<0.05 ;{ }^{*} \mathrm{p}<0.10 \text {. }\end{array}$} \\
\hline
\end{tabular}


Table VII. Effects of the Unemployment Rate on Teen Girls Aged 15-17 Time Use (ATUS 2003-2011)

\begin{tabular}{|c|c|c|c|c|}
\hline Dependent Variable & $\mathbf{N}$ & Mean & Urate & $\mathbf{R}^{2}$ \\
\hline Minutes with Mother & 1,974 & 126.45 & $4.749(6.160)$ & 0.097 \\
\hline Minutes with Father & 1,974 & 66.94 & $4.407(4.217)$ & 0.147 \\
\hline Minutes in Class & 1,974 & 215.86 & $6.502(5.074)$ & 0.084 \\
\hline $\mathrm{NBNH}$ & 1,453 & 214.91 & $-2.983(4.744)$ & 0.098 \\
\hline Non-Hispanic Black & 204 & 224.68 & $5.387(24.219)$ & 0.462 \\
\hline Hispanic & 317 & 212.76 & $25.430 *(14.586)$ & 0.274 \\
\hline Minutes of Homework & 1,974 & 60.19 & $2.048(3.235)$ & 0.120 \\
\hline Minutes of Homework \& Extracurricular Activities & 1,974 & 69.06 & $1.804(3.137)$ & 0.126 \\
\hline Minutes of Total Education & 1,974 & 284.93 & $8.307(6.698)$ & 0.092 \\
\hline Minutes in Sports & 1,974 & 24.88 & $0.565(1.710)$ & 0.073 \\
\hline Minutes Sleeping on Diary Day & 1,974 & 543.37 & $-5.424 *(2.836)$ & 0.075 \\
\hline Minutes Sleeping on Night Following Diary Day & 1,974 & 511.65 & $-6.505(4.123)$ & 0.062 \\
\hline Minutes TV & 1,974 & 117.06 & $-8.957 * *(4.190)$ & 0.088 \\
\hline Minutes Games and TV & 1,974 & 146.85 & $-5.680(4.486)$ & 0.087 \\
\hline
\end{tabular}

Note: Unemployment rates are measured at the state-level and all specifications include state and year fixed effects. ATUS final weights used. Standard errors adjusted for clustering by state are reported in parentheses. Control variables include mother and father's age and age squared $\ln ($ minimum wage), state minimum driving license age, state maximum compulsory schooling age, and indicators for age, mother's and father's education level (high school dropout, some college, college, missing), family structure (single mother, single father), race and ethnicity (non-Hispanic black, Hispanic), $1^{\text {st }}$ or $2^{\text {nd }}$ generation immigrant, age of youngest household child (infant, preschooler, elementary), number of household children (two, three or more), household child older than age 18, lives with other adults, gender composition of the children (all boy, mixed gender), season, and respondent lives in SMSA. Significance levels: *** $\mathrm{p}<0.01 ; * * \mathrm{p}<0.05 ; * \mathrm{p}<0.10$. 


\section{APPENDIX}

Appendix Table A1. YRBS Teens Aged 15-17 Sample Selection (2003-2011)

Number of

Observations

\begin{tabular}{lc}
\hline All Teens & 74,962 \\
Drop teens missing age & 74,669 \\
Drop teens missing gender & 74,549 \\
Drop teens missing grade in school & 74,310 \\
Drop teens missing race/ethnicity & 73,375 \\
Teens aged 15-17 only & 54,664 \\
\hline FEMALE TEENS & 26,770 \\
MALE TEENS & 27,894 \\
\hline
\end{tabular}


Appendix Table A2. Sample Means and Proportions (YRBS 2003-2011)

\begin{tabular}{|c|c|c|}
\hline & $\begin{array}{c}\text { Male } \\
(\mathrm{N}=26,770)\end{array}$ & $\begin{array}{c}\text { Female } \\
(\mathrm{N}=26,988)\end{array}$ \\
\hline \multicolumn{3}{|l|}{ Dependent Variables: } \\
\hline Sexual Intercourse in Past Three Months & 0.33 & 0.35 \\
\hline Contraceptive Use at Last Intercourse & 0.89 & 0.86 \\
\hline Smoke in Past 30 Days & 0.20 & 0.20 \\
\hline Smoke Daily in Past 30 Days & 0.06 & 0.06 \\
\hline Alcohol Use in Past 30 Days & 0.42 & 0.43 \\
\hline Marijuana in Past 30 Days & 0.24 & 0.19 \\
\hline Overweight & 0.32 & 0.25 \\
\hline Obese & 0.16 & 0.10 \\
\hline \multicolumn{3}{|l|}{ Economic Conditions: } \\
\hline $\begin{array}{l}\text { State yearly unemployment rate } \\
\text { [overall min } 2.90, \max 13.70 \text { ] }\end{array}$ & 6.33 & 6.32 \\
\hline \multicolumn{3}{|l|}{ Individual Characteristics: } \\
\hline Age 15 & 0.34 & 0.34 \\
\hline Age 16 & 0.35 & 0.34 \\
\hline Age 17 & 0.31 & 0.32 \\
\hline $\mathrm{NBNH}$ & 0.69 & 0.68 \\
\hline Non-Hispanic Black & 0.14 & 0.15 \\
\hline Hispanic & 0.17 & 0.17 \\
\hline Grade 9 & 0.24 & 0.21 \\
\hline Grade 10 & 0.35 & 0.34 \\
\hline Grade 11 & 0.29 & 0.31 \\
\hline Grade 12 & 0.12 & 0.14 \\
\hline Year $=2003$ & 0.21 & 0.20 \\
\hline Year $=2005$ & 0.18 & 0.19 \\
\hline Year $=2007$ & 0.18 & 0.19 \\
\hline Year $=2009$ & 0.22 & 0.22 \\
\hline Year $=2011$ & 0.21 & 0.20 \\
\hline \multicolumn{3}{|l|}{ State Laws: } \\
\hline Ln(Minimum Wage) & 1.15 & 1.15 \\
\hline Minimum Driver's License Age & 16.07 & 16.08 \\
\hline Maximum Compulsory Schooling Age & 17.04 & 17.03 \\
\hline State Cigarette Price & 2.25 & 2.25 \\
\hline
\end{tabular}

Note: Estimates are weighted and based upon non-missing values. 
Appendix Table A3. Effects of the Unemployment Rate on Teenagers' Risky Behaviors for Teens Ages12-18, by Gender and Race/Ethnicity (YRBS 2003-2011)

\begin{tabular}{|c|c|c|c|c|c|c|c|c|}
\hline Sample & $\begin{array}{c}\text { Sexual } \\
\text { Intercourse in } \\
\text { Past Three } \\
\text { Months } \\
\end{array}$ & $\begin{array}{c}\text { Contraceptive } \\
\text { Use if Sexual } \\
\text { Intercourse } \\
\end{array}$ & $\begin{array}{c}\text { Smoke in } \\
\text { Past } 30 \\
\text { Days }\end{array}$ & $\begin{array}{c}\text { Smoke } \\
\text { Every Day } \\
\text { in Past } 30 \\
\text { Days } \\
\end{array}$ & $\begin{array}{l}\text { Alcohol Use in } \\
\text { Past } 30 \text { Days }\end{array}$ & $\begin{array}{l}\text { Marijuana in } \\
\text { Past } 30 \text { Days }\end{array}$ & Overweight & Obese \\
\hline \multicolumn{9}{|c|}{ Panel 1. Boys } \\
\hline \multirow[t]{2}{*}{ All } & 0.002 & -0.006 & 0.006 & 0.005 & 0.009 & 0.002 & 0.000 & 0.003 \\
\hline & $(0.007)$ & $(0.005)$ & $(0.008)$ & $(0.004)$ & $(0.008)$ & $(0.006)$ & $(0.006)$ & $(0.005)$ \\
\hline \multirow[t]{2}{*}{ NBNH } & 0.008 & $-0.014^{*}$ & 0.006 & 0.003 & 0.007 & -0.007 & 0.004 & 0.003 \\
\hline & (0.009) & $(0.008)$ & (0.009) & $(0.006)$ & (0.008) & (0.007) & (0.009) & $(0.006)$ \\
\hline \multirow[t]{2}{*}{ Black } & -0.023 & 0.009 & 0.013 & 0.006 & -0.010 & $0.018 * *$ & -0.012 & 0.009 \\
\hline & (0.014) & (0.011) & $(0.014)$ & $(0.006)$ & $(0.014)$ & $(0.009)$ & (0.012) & $(0.009)$ \\
\hline \multirow[t]{2}{*}{ Hispanic } & 0.009 & 0.002 & 0.009 & 0.002 & $0.028 * * *$ & $0.010 *$ & -0.000 & 0.008 \\
\hline & $(0.007)$ & $(0.009)$ & $(0.009)$ & $(0.003)$ & $(0.007)$ & $(0.005)$ & $(0.009)$ & $(0.008)$ \\
\hline $\mathrm{N}$ (All) & 32,403 & 11,309 & 34,155 & 34,155 & 32,975 & 35123 & 34,029 & 34,029 \\
\hline \multicolumn{9}{|c|}{ Panel 2. Girls } \\
\hline \multirow[t]{2}{*}{ All } & 0.004 & -0.004 & 0.005 & $0.006 *$ & 0.009 & 0.003 & -0.002 & -0.004 \\
\hline & $(0.009)$ & $(0.005)$ & $(0.007)$ & $(0.003)$ & $(0.006)$ & $(0.006)$ & $(0.007)$ & $(0.004)$ \\
\hline \multirow[t]{2}{*}{ NBNH } & 0.011 & -0.004 & 0.008 & 0.008 & 0.008 & 0.005 & 0.005 & 0.002 \\
\hline & $(0.012)$ & $(0.006)$ & $(0.010)$ & $(0.005)$ & $(0.011)$ & $(0.008)$ & $(0.009)$ & $(0.005)$ \\
\hline \multirow[t]{2}{*}{ Black } & 0.000 & 0.004 & -0.008 & 0.001 & 0.016 & -0.009 & -0.003 & -0.016 \\
\hline & $(0.010)$ & $(0.014)$ & $(0.007)$ & $(0.003)$ & $(0.010)$ & $(0.008)$ & $(0.014)$ & $(0.011)$ \\
\hline \multirow[t]{2}{*}{ Hispanic } & -0.008 & -0.007 & 0.001 & 0.004 & -0.004 & 0.003 & -0.014 & -0.003 \\
\hline & (0.009) & (0.009) & $(0.008)$ & $(0.003)$ & $(0.007)$ & (0.009) & $(0.010)$ & $(0.004)$ \\
\hline N (All) & 34,169 & 12,270 & 35,831 & 35,831 & 34,494 & 36,535 & 34,495 & 34,495 \\
\hline
\end{tabular}

Notes: Linear probability models were estimated. YRBS weights used. Standard errors adjusted for clustering by state are reported in parentheses. Control variables include indicators for age, race and ethnicity (non-Hispanic black, other, Hispanic), grade in school, state laws (max compulsory schooling age, $\ln [$ minimum wage], minimum driver's license age), state and year fixed effects. In the smoking regressions, I also include the state cigarette price. Significance levels: ${ }^{* * *} \mathrm{p}<0.01 ;{ }^{* *} \mathrm{p}<0.05{ }^{*} \mathrm{p}<0.10$. 
Appendix Table A4. Effects of the Unemployment Rate on Teenage Risky Behaviors for Teens Aged 12-18, by Gender and Race/Ethnicity (YRBS 1991-2011)

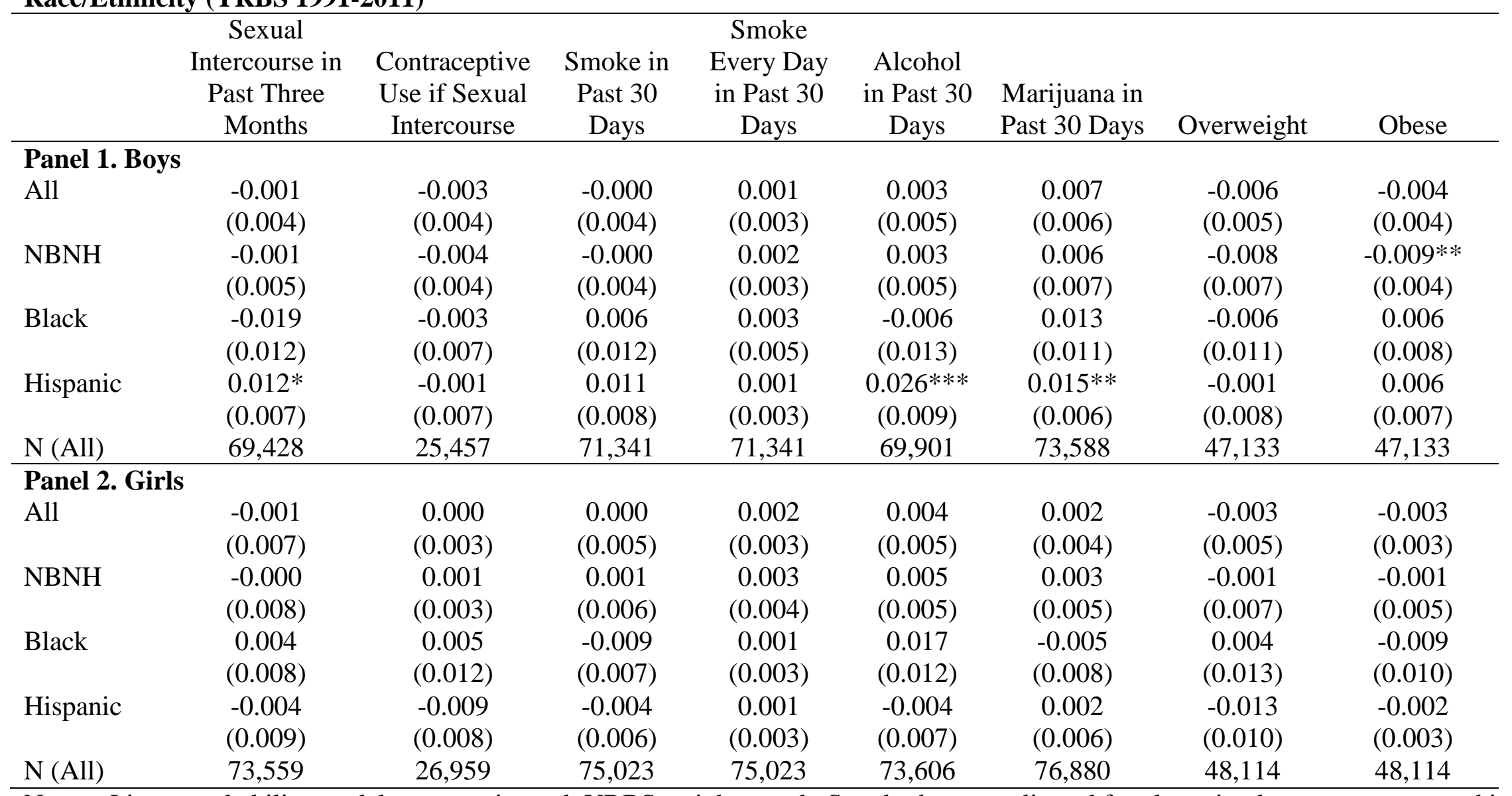

Notes: Linear probability models were estimated. YRBS weights used. Standard errors adjusted for clustering by state are reported in parentheses. Control variables include indicators for age, race and ethnicity (non-Hispanic black, other, Hispanic), grade in school, state laws (max compulsory schooling age, $\ln [$ minimum wage], minimum driver's license age), state and year fixed effects. In the smoking regressions, I also include the state cigarette price. Significance levels: ${ }^{* * *} \mathrm{p}<0.01 ;{ }^{* *} \mathrm{p}<0.05 ;{ }^{*} \mathrm{p}<0.10$. 
Appendix Table A5. ATUS Teen Sample Selection 2003-2011

\begin{tabular}{lc}
\hline Teens aged 15-17 & 5,863 \\
Teens who live with at least one heterosexual parent & 5,660 \\
Drop teens who are married or cohabitating & 5,645 \\
Drop teens who have their own children & 5,613 \\
Drop teens whose parent is missing education & 5,580 \\
Drop those who slept more than 20 hours on diary day & 5,572 \\
Drop those sick more than 4 hours on diary day & 5,566 \\
Drop those interviewed in summer months (between Memorial & 4,120 \\
Day and Labor Day) & \\
\hline FEMALE TEENS & 1,974 \\
MALE TEENS & 2,146 \\
\hline
\end{tabular}


Table A6. Teenagers' Mean Characteristics (ATUS 2003-2011)

\begin{tabular}{|c|c|c|}
\hline & $\begin{array}{l}\text { Boys } \\
(N=2,146)\end{array}$ & $\begin{array}{l}\text { Girls } \\
(\mathrm{N}=1,974)\end{array}$ \\
\hline \multicolumn{3}{|l|}{ Economic conditions: } \\
\hline $\begin{array}{l}\text { State Yearly Unemployment Rate } \\
\text { [Overall min 2.49, max 13.80] }\end{array}$ & 6.41 & 6.43 \\
\hline \multicolumn{3}{|l|}{ Individual characteristics: } \\
\hline NBNH & 0.63 & 0.68 \\
\hline Hispanic & 0.23 & 0.18 \\
\hline Non-Hispanic Black & 0.15 & 0.14 \\
\hline Age 15 & 0.27 & 0.28 \\
\hline Age 16 & 0.36 & 0.38 \\
\hline Age 17 & 0.37 & 0.34 \\
\hline Immigrant & 0.24 & 0.22 \\
\hline Live with both parents & 0.74 & 0.71 \\
\hline Live with single mother & 0.21 & 0.24 \\
\hline Live with single father & 0.05 & 0.04 \\
\hline Mother's age & 43.98 & 44.05 \\
\hline Father's age & 46.62 & 46.77 \\
\hline Mother high school dropout & 0.14 & 0.13 \\
\hline Mother high school & 0.26 & 0.25 \\
\hline Mother some college & 0.32 & 0.31 \\
\hline Mother college & 0.28 & 0.31 \\
\hline Father high school dropout & 0.16 & 0.12 \\
\hline Father high school & 0.27 & 0.28 \\
\hline Father some college & 0.25 & 0.25 \\
\hline Father college & 0.33 & 0.35 \\
\hline Two children in household & 0.18 & 0.21 \\
\hline Three or more children in household & 0.12 & 0.12 \\
\hline Youngest child infant & 0.05 & 0.04 \\
\hline Youngest child preschooler & 0.06 & 0.06 \\
\hline Youngest child elementary student & 0.27 & 0.28 \\
\hline Child older than 18 in household & 0.26 & 0.24 \\
\hline All boy household children & 0.58 & 0.57 \\
\hline Mixed gender household children & 0.18 & 0.20 \\
\hline Live with other adults & 0.33 & 0.31 \\
\hline Resides in SMSA & 0.84 & 0.86 \\
\hline Fall & 0.33 & 0.33 \\
\hline Winter & 0.33 & 0.36 \\
\hline Spring & 0.34 & 0.31 \\
\hline \multicolumn{3}{|l|}{ State Laws: } \\
\hline Ln (minimum wage) & 1.13 & 1.13 \\
\hline Minimum driver's license age & 16.07 & 16.08 \\
\hline Maximum compulsory schooling age & 17.17 & 17.18 \\
\hline
\end{tabular}

Notes: Survey weights used. Mother's and father's age and education means are for nonmissing observations due to differences in family structure. 


\begin{tabular}{|c|c|c|}
\hline & Boys & Girls \\
\hline $\begin{array}{l}\text { Urate } \\
\end{array}$ & $\begin{array}{l}-7.425^{*} \\
(3.911)\end{array}$ & $\begin{array}{c}4.309 \\
(6.835)\end{array}$ \\
\hline Live with single mother & $\begin{array}{c}-40.261^{* * * *} \\
(12.528)\end{array}$ & $\begin{array}{l}-26.878^{*} \\
(13.752)\end{array}$ \\
\hline Live with single father & $\begin{array}{c}-47.250^{* * * *} \\
(17.484)\end{array}$ & $\begin{array}{c}-62.221^{* * *} \\
(21.561)\end{array}$ \\
\hline Hispanic & $\begin{array}{c}-3.603 \\
(10.346)\end{array}$ & $\begin{array}{l}31.909^{*} \\
(16.600)\end{array}$ \\
\hline Non-Hispanic black & $\begin{array}{c}-25.738^{*} \\
(13.190)\end{array}$ & $\begin{array}{l}-15.501 \\
(12.942)\end{array}$ \\
\hline Immigrant & $\begin{array}{l}-10.030 \\
(9.597)\end{array}$ & $\begin{array}{c}1.836 \\
(11.117)\end{array}$ \\
\hline Age 16 & $\begin{array}{c}-18.461^{*} \\
(10.849)\end{array}$ & $\begin{array}{l}-10.515 \\
(12.016)\end{array}$ \\
\hline Age 17 & $\begin{array}{c}-24.778^{* *} \\
(11.122)\end{array}$ & $\begin{array}{c}-23.608^{* *} \\
(11.131)\end{array}$ \\
\hline Mother's age & $\begin{array}{l}-0.169 \\
(6.130)\end{array}$ & $\begin{array}{l}-3.602 \\
(5.671)\end{array}$ \\
\hline Mother's age squared & $\begin{array}{c}-5.785 \\
(70.266)\end{array}$ & $\begin{array}{c}30.256 \\
(63.384)\end{array}$ \\
\hline Father's age & $\begin{array}{c}11.874 * * \\
(4.682)\end{array}$ & $\begin{array}{l}-0.978 \\
(5.893)\end{array}$ \\
\hline Father's age squared & $\begin{array}{c}-108.720 * * \\
(49.507)\end{array}$ & $\begin{array}{c}9.198 \\
(59.720)\end{array}$ \\
\hline Mother HS dropout & $\begin{array}{c}-1.006 \\
(12.245)\end{array}$ & $\begin{array}{c}25.164 \\
(18.602)\end{array}$ \\
\hline Mother some college & $\begin{array}{c}-3.525 \\
(11.684)\end{array}$ & $\begin{array}{c}3.759 \\
(13.104)\end{array}$ \\
\hline Mother college & $\begin{array}{c}-7.832 \\
(11.488)\end{array}$ & $\begin{array}{l}-12.478 \\
(13.722)\end{array}$ \\
\hline Father HS dropout & $\begin{array}{c}-1.727 \\
(13.369)\end{array}$ & $\begin{array}{l}-43.375 \\
(30.316)\end{array}$ \\
\hline Father some college & $\begin{array}{c}8.563 \\
(10.046)\end{array}$ & $\begin{array}{c}1.777 \\
(13.067)\end{array}$ \\
\hline Father college & $\begin{array}{c}25.587 * * \\
(12.390)\end{array}$ & $\begin{array}{c}12.856 \\
(14.987)\end{array}$ \\
\hline Two children in household & $\begin{array}{c}-6.343 \\
(10.514)\end{array}$ & $\begin{array}{l}-8.638 \\
(9.804)\end{array}$ \\
\hline Three or more children in household & $\begin{array}{c}-10.867 \\
(18.160)\end{array}$ & $\begin{array}{l}-35.077^{*} \\
(18.899)\end{array}$ \\
\hline Youngest child infant & $\begin{array}{c}6.018 \\
(20.861)\end{array}$ & $\begin{array}{c}20.444 \\
(20.372)\end{array}$ \\
\hline Youngest child preschooler & $\begin{array}{c}5.589 \\
(17.290)\end{array}$ & $\begin{array}{c}22.947 \\
(27.897)\end{array}$ \\
\hline
\end{tabular}


Youngest child elementary student

1.791

(11.573)

Child older than 18 in $\mathrm{HH}$

$-19.054$

(13.429)

11.205

(7.556)

19.541

(12.894)

12.256

(11.764)

$-10.107$

(12.451)

$-2.420$

(9.963)

1.557

(8.379)

$-28.433$

(57.534)

State minimum driver’s license age

State maximum compulsory schooling age

Year $=2003$

Year $=2004$

Year $=2006$

Year $=2007$

Year $=2008$

Year $=2009$

Year $=2010$

Year $=2011$

Observations

R-squared

Notes: This is the full set of covariates from the first row of sample. Regressions also include state fixed effects and a constant. Standard errors adjusted for clustering by state are reported in parentheses. Significance levels: *** $\mathrm{p}<0.01 ;{ }^{* *} \mathrm{p}<0.05 ;{ }^{*} \mathrm{p}<0.10$. 